\title{
Assessment of Agricultural Sustainability in Some Areas West of Nile Delta
}

\author{
E. S. Mohamed ${ }^{1}$ and M. S. Gouda ${ }^{2}$ \\ ${ }^{1}$ National Authority for Remote Sensing and Space Sciences, Cairo and ${ }^{2}$ Soil \\ Department, Faculty of.Agricultyre, Damitta Unversity, Damitta,Egypt
}

\begin{abstract}
OUSTAINABLE agriculture aims at improving the production besides the conservation $\mathcal{O}_{\text {of natural resources. Egypt has a lot of sustainability obstacles facing agricultural }}$ development; some of them belong to soil characteristics such as soil salinity, soil type and others belong to environmental hazards and socio economic factors. The present study focuses on assessing sustainable agricultural status in west of the Nile delta by integration of physical, social and economic factors using GIS. The present study focused on five pillars for evaluating sustainability levels for agricultural development under Egyptian conditions; soil productivity, security, protection, social acceptability and economic feasibility in the different mapping units. The results showed that, the study area is classified into three classes: II, III, and IV which occupy an area of about $11.22,64.92$, and $12.08 \%$ respectively. The results illustrate the current state of agricultural sustainability where, the values of sustainability varying between 0.1 and 0.36 . About $48 \%$ of the total study area is characterized by a very low degree of sustainability $<0.1$ as it is classified as IV. This study proposed some recommendations to improve the current status of sustainable development such as increasing the number of markets, schools and health care, loan facilitation, and educating farmers modern methods of good management. The proposed recommendations will improve the sustainability degree by $10 \%$ of the study area.
\end{abstract}

Keywords: Sustainable agriculture, West of Nil Delta, Remote sensing, GIS

\section{Introduction}

The concept of sustainable agriculture development is used to illustrate the current and future needs of the population as well as, sustainability of the resources and food to ensure the availability of food for future generations. furthermore, aims to improve and maintain natural resources and ecosystem services (USAID. 1988. and Smyth \& Dumanski, 1993 and Tilman et al., 2002). In addition, sustainable agriculture development revolves around three axes, economic profitability, social and economic equity and environmental conditions (Bell and Morse, 2008). Sustainable agricultural may include intensification, agro-ecological and the advanced -tech industrial applications. It is linked to soil productivity and natural conditions (Muller et al., 2017). Agricultural sustainability aims also to enhance the agricultural means which control the input and output and reduce the pollution of food (El-Ramady et al., 2013). Sustainable agricultural differs from a region to another, as it is affected by the local environmental conditions of each country; sustainable agricultural in
Egypt is effected by population intensity and urban encroachment as well as socio-economic conditions (Mohamed et al., 2018). There are several parameters used to evaluate sustainable agricultural such as soil productivity, socioand economic conditions beside soil sensitivity to erosion hazards by both water and wide (Dumanski, 1997). Moreover, the sustainable development is not easy to be evaluated where it is linked with numerous factors and needs an integration of socio-economic conditions with surrounding environment factors. The sustainable agricultural issue is still not implemented yet in many countries especially the developing countries, although it is very important to conduct a comprehensive evaluation of sustainable development, where the evaluation is the first step towards real development (Mohamed, 2014 and Gliessman, 1998). In addition the scientific researchers aim to link the results of their research on sustainable development to the practices of decision-makers (Antonson, 2009). Biomass is used as a good indicator for soil productivity then reflects on sustainable agriculture at the long run

\footnotetext{
*Corresponding author: salama55@mail.ru

DOI :10.21608/ejss.2018.3727.1176

(C)2018 National Information and Documentation Center (NIDOC)
} 
(El-Nahry, 2001). Biophysics components such as soil productivity, soil erosion, socio-economic conditions and security are integrated together by GIS to evaluate sustainable agricultural in some areas in Egypt (Nawar, 2009 and Mohamed et al., 2018). The same authors have identified the main obstacles to agricultural development in Egypt, like salinity and soil alkalinity, beside economic and social factors. Soil production is affected by social development in many respects and varies from geospatial location to another. At this point, the analysis of sustainability on a small local scale is high accurate to illustrate the heterogeneity in agricultural development levels (Simon, 2000). Sustainable agriculture can be promoted through implementing precise management programs suitable to the farm conditions, including procedures of land and water conservation practices (Eswaran et al., 2000). The expansion of agricultural development system is illustrated by Sharmaa et al. (2006) and Matthews et al., 2008), who illustrated potential sustainable agricultural development in British Columbia. Recently remote sensing and GIS modeling have been used to clarify the probability of sustainable development where, the main aim of these models is the emulation of potential use of land in different screenplay beside the evaluation of environmental effects and soci-economic conditions (Mohamed et al., 2018).

The main object of this study is to evaluate the current status of sustainable agriculture in west of Nile Delta using GIS spatial modeling by integrating some factors such as security, protection, productivity security, social and economic acceptability. Also, it aims to study the potentiality for improving sustainable agriculture development of the study area.

\section{Materials and Methods}

\section{Location of study area}

The investigated area is lying at west of Nile Delta, between longitudes $29^{\circ} 27^{\prime} 30^{\prime \prime}$ to $29^{\circ} 52^{\prime}$ $0^{\prime \prime}$ east, and latitudes $30^{\circ} 45^{\prime} 00^{\prime \prime}$ to $30^{\circ} 57^{\prime} 30^{\prime \prime}$ North as shown in Fig. 1. The territory is climatically characterized of a rainy winter and a hot dry summer as Mediterranean climate. The amount of annual downpour fall in winter between October and March where, it ranges between 150 to 200 $\mathrm{mm} /$ year . The maximum monthly temperature is $33^{\circ} \mathrm{C}$ in July, the minimum temperature is $9.5^{\circ}$ $\mathrm{C}$ in January, and the mean annual temperature is $25^{\circ} \mathrm{C}$.

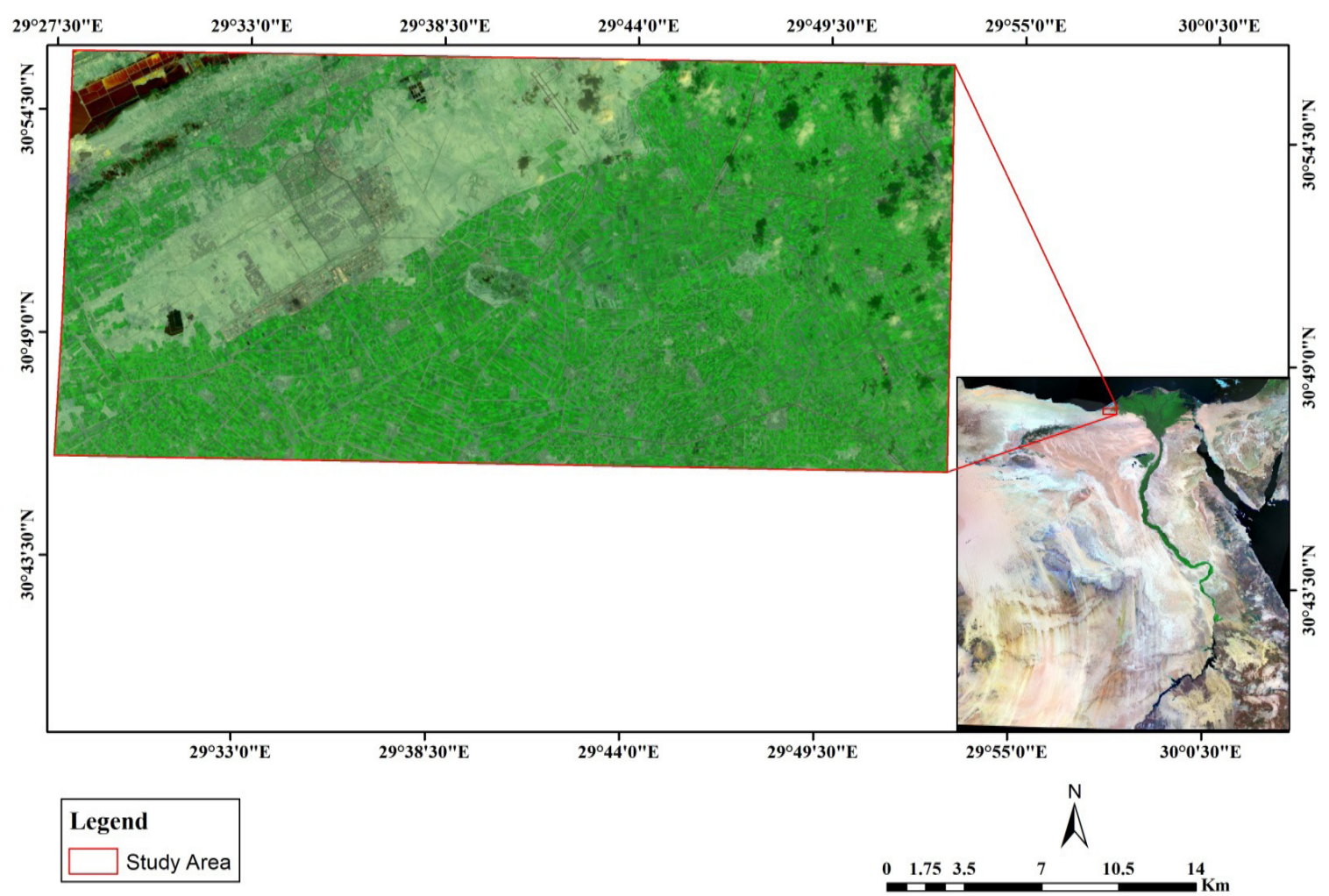

Fig. 1. Location of the study area. 


\section{Physiographic map}

The Physiographic map of the investigated area is produced based on integration of topographic elements slope, aspect, curvature and relief intensity sing GIS.

\section{Image processing}

The study was conducted using Operational Land Imager (OLI) satellite images. The OLI image pre-processing procedures composed of atmospheric correction and image enhancement. Digital elevation model (DEM) of the study was derived using ASTER DEM images as it exports the elevation heights of the investigated area .The OLI image was draped over DEM to get the simulation of natural $3 \mathrm{D}$ then, used for differentiating the different Land use- land cover for the investigated area.

\section{Field study and laboratory analyses}

Field studies and ground verification were accomplished based on a physiographic map. 16 soil profiles were dug representing various physiographic units of the study area. The soil samples were collected and air-dried, ground gently, then sieved through a $2 \mathrm{~mm}$ sieve. Physical and chemical analyses were conducted that inclusive particle size distribution, electrical conductivity organic matter, bulk density, $\mathrm{pH}$, according to USDA (2004).

\section{Assessment of sustainable agricultural}

The evaluation of agricultural sustainability was based on the proposed framework by Smyth and Dumanski (1993). The framework of sustainable land management was used to assess the current status of sustainability including the current land use and environmental conservation, management practices, and socio economic situations and its potential for future development. All the parameters affecting sustainable agricultural were analyzed in the first step, where questionnaires were recorded, as well as monitoring the available information about the social and cultural aspects of the farmers, as well as evaluating the available health care in the study area. Then, the factors were determined to estimate sustainability levels. In the third step, the potential sustainability is modeled based on the implementation of the recommendations is assumed to obtain the expected results in the future.

\section{Evaluation of productivity index}

Soil productivity index includes a set off parameters affecting the quantity of yield either positivly or negativly. Eight parameters (yield , organic matter, $\mathrm{pH}$, cation exchange capacity, soil profile depth, soil salinity, exchangeable sodium percentage and soil texture have been used to calculate soil productivity. Tables 1 and 2 illustrate the parameters used in calculation of soil productivity index using the following formula:

Soil productivity index $=$

$$
\frac{A}{100} X \frac{B}{100} X \frac{C}{100} X \frac{D}{100} X \frac{E}{100} X \frac{F}{100} X \frac{G}{100} X \frac{H}{100}
$$

where: yield \% (A), OM \% (B), pH (C), CEC (D), profile depth (E), EC (F), ESP \% (G) and texture $(\mathrm{H})$.

\section{Evaluation of security and protection indices}

Security index shows the relation between biomass and water quality therefore, three factors have been used to evaluate security index; moisture availability (A), water quality (B) and biomass (C). The protection index shows the sensitivity degree to erosion hazards by both wind and water. It is calculated based on determination of erosion hazards by water and wind (A), flooding hazards (B) and cropping system (C) using the following formulas:

$$
\begin{aligned}
& \text { Security index }=\frac{A}{100} \times \frac{B}{100} \times \frac{C}{100} \\
& \text { Protection Index }=\frac{A}{100} \times \frac{B}{100} \times \frac{C}{100}
\end{aligned}
$$

\section{Evaluation of economic viability index}

The assessment of economic index depends on several factors related to the local economic situation of each region, where it varies from a place to another. From this point, the evaluation included the following; product prices, transport costs, net farm profit, the availability of markets, ...etc. In the current study, all the information was collected through the field visit. The following parameters were used, benefit-cost ratio (A), difference between farm gate price and the nearest main market price (B), availability of farm labor (C), size of farm holding (D) and the percentage of farm product sold in the market $(\mathrm{E})$ is given by:

Economic viability index $=$

$$
\frac{A}{100} \times \frac{B}{100} \times \frac{C}{100} \times \frac{D}{100} \times \frac{E}{100}
$$

Six factors have been used to calculate the adequacy of social conditions:

Egypt. J. Soil Sci., 58, No. 3 (2018) 
Tenure of farms (A), extension support services (B), educational and health facilities (C), water conservation degree (D) , availability of agroinputs within 5-10 km range (E) and efficient of road network (F). The west of Nile delta region has suffered throughout the previous decades of neglect in infrastructure, education and health facilities.

Social acceptability Index $=$

$$
\frac{A}{100} X \frac{B}{100} X \frac{C}{100} X \frac{D}{100} X \frac{E}{100} X \frac{F}{100}
$$

TABLE 1. Productivity characteristics of the studied soil mapping units.

\begin{tabular}{|c|c|c|c|c|c|c|c|c|}
\hline \multirow[b]{2}{*}{ Mapping unit } & \multirow{2}{*}{$\begin{array}{c}\text { Relative } \\
\text { yield } \\
(\%)\end{array}$} & \multicolumn{3}{|c|}{ Nutrient availability } & \multirow{2}{*}{$\begin{array}{c}\text { Water } \\
\text { table } \\
\text { Depth } \\
\text { (cm) }\end{array}$} & \multirow{2}{*}{$\begin{array}{l}E C \\
(d S \\
\left.m^{-1}\right)\end{array}$} & \multirow[b]{2}{*}{$\begin{array}{l}\text { ESP } \\
(\%)\end{array}$} & \multirow[b]{2}{*}{ Texture } \\
\hline & & $\begin{array}{c}\text { Organic } \\
\text { carbon } \\
(\%) \\
\end{array}$ & pH & $\begin{array}{c}\text { CEC } \\
\text { (meq/100 g } \\
\text { soil) }\end{array}$ & & & & \\
\hline Sand Plain & 0.22 & 0.52 & 7.99 & 19.27 & 130 & 1.26 & 8.61 & Loam \\
\hline High Over Flow Basin & 0.34 & 0.47 & 7.95 & 11.58 & 135 & 0.71 & 5.58 & $\begin{array}{l}\text { sandy } \\
\text { loam }\end{array}$ \\
\hline Decantation Basin & 0.31 & 0.47 & 7.77 & 14.02 & 150 & 1.27 & 3.78 & Loam \\
\hline Low Over Flow Basin & 0.18 & 0.48 & 7.74 & 11.33 & 125 & 1.95 & 7.70 & $\begin{array}{l}\text { sandy } \\
\text { loam }\end{array}$ \\
\hline Table Land & 0.19 & 0.50 & 8.04 & 10.05 & - & 0.39 & 3.75 & silt loam \\
\hline Ridge & 0.14 & 0.45 & 7.69 & 19.38 & - & 0.67 & 4.9 & sandy \\
\hline Inter Ridge slope & 0.20 & 0.64 & 8.01 & 15.69 & 130 & 0.94 & 8.14 & Loam \\
\hline
\end{tabular}

\section{Sustainable agricultural}

The present study aims to evaluate the current situation of sustainable agricultural of the study area. Five key factors mentioned above were directly related to agricultural sustainability. During the present study, each factor of sustainability was mapped using GIS techniques.

\section{Soil productivity index}

Soil productivity index relates to fertility status of soil and its nutrient content and its availability for plant absorption. Therefore, chemical and physical properties are taken into account in assessing of soil productivity based on the eight factors mentioned above. As results indicated that, soil texture are varying between loam, sandy loam, and silt loam in the different layers

\section{$\underline{\text { Results and Discussion }}$}

Physiographic map of the study area

Physiographic units were identified throughout interpreting satellite image as well as digital elevation model of the study area. The Physiographic units were recognized and delineated by analyzing the main landscape with the aid of the different maps and field survey. The obtained results showed that the study area is including the following units ;sand plain, inter ridge depression, decantation basin, high over flow basin ,low over flow basin, moderately over flow basin ,table land, ridge, inter ridge slope as shown in Fig. 2. 


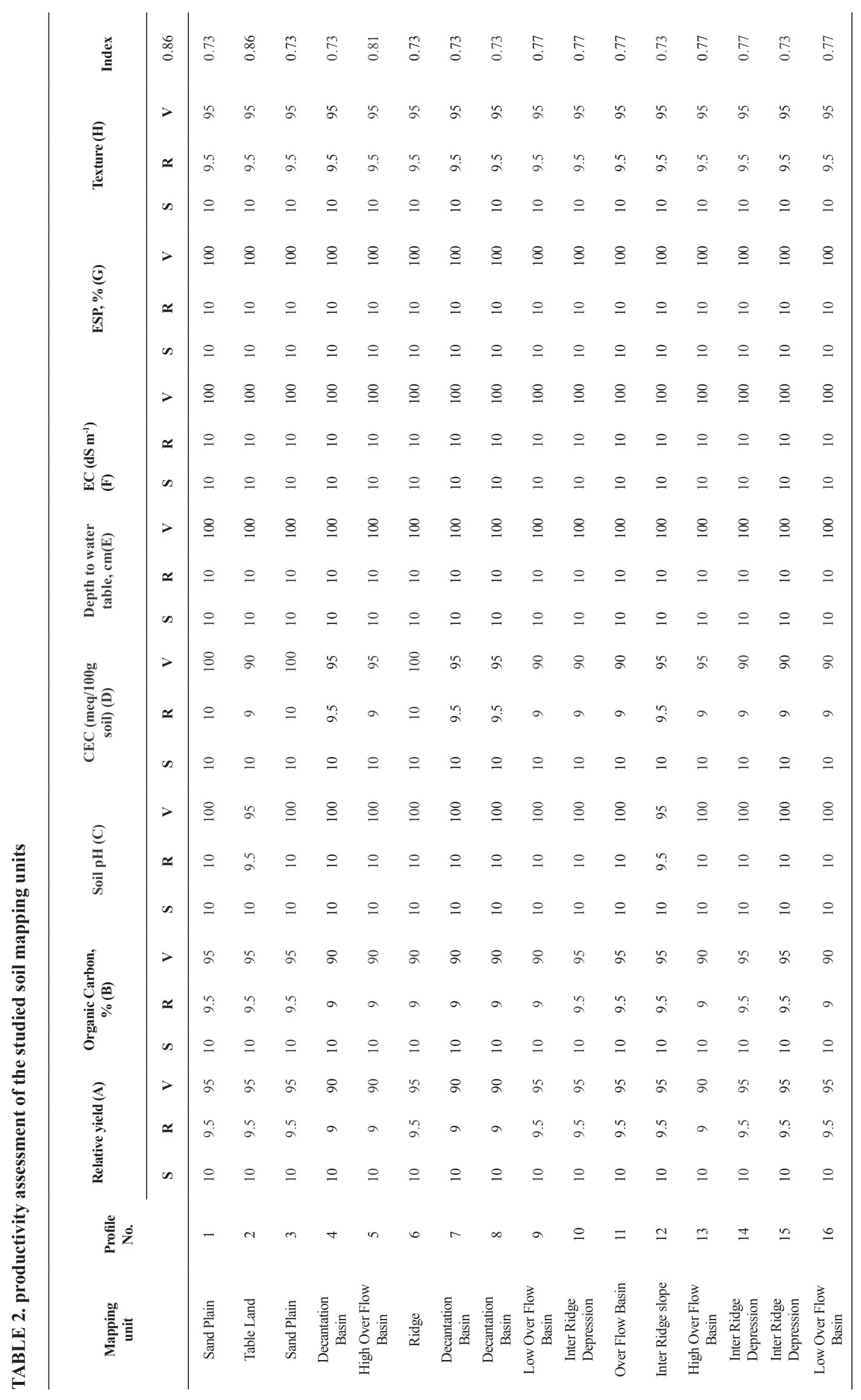

Egypt. J. Soil Sci., 58, No. 3 (2018) 
$35 \%$ which contains layers of lime. According to the heterogeneity of the soil properties, soil productivity was also found to vary according to its properties and geospatial location in addition to, the other surrounding factors such as slope levels and differs in Physiographic units. The results showed that, sand plain and some parts of ridges is described as a high productive soil where, its index reaches $>0.81$. Inter ridge depression, Inter ridge slope and over flow basin are described by moderate productivity index (0.77). Furthermore, mapping units of High over flow basin, some parts of decantation basin, Low over flow basin, and Table land are attributed by moderate to high soil productivity $(0.73)$ as shown in Table 2 and Fig. 3.

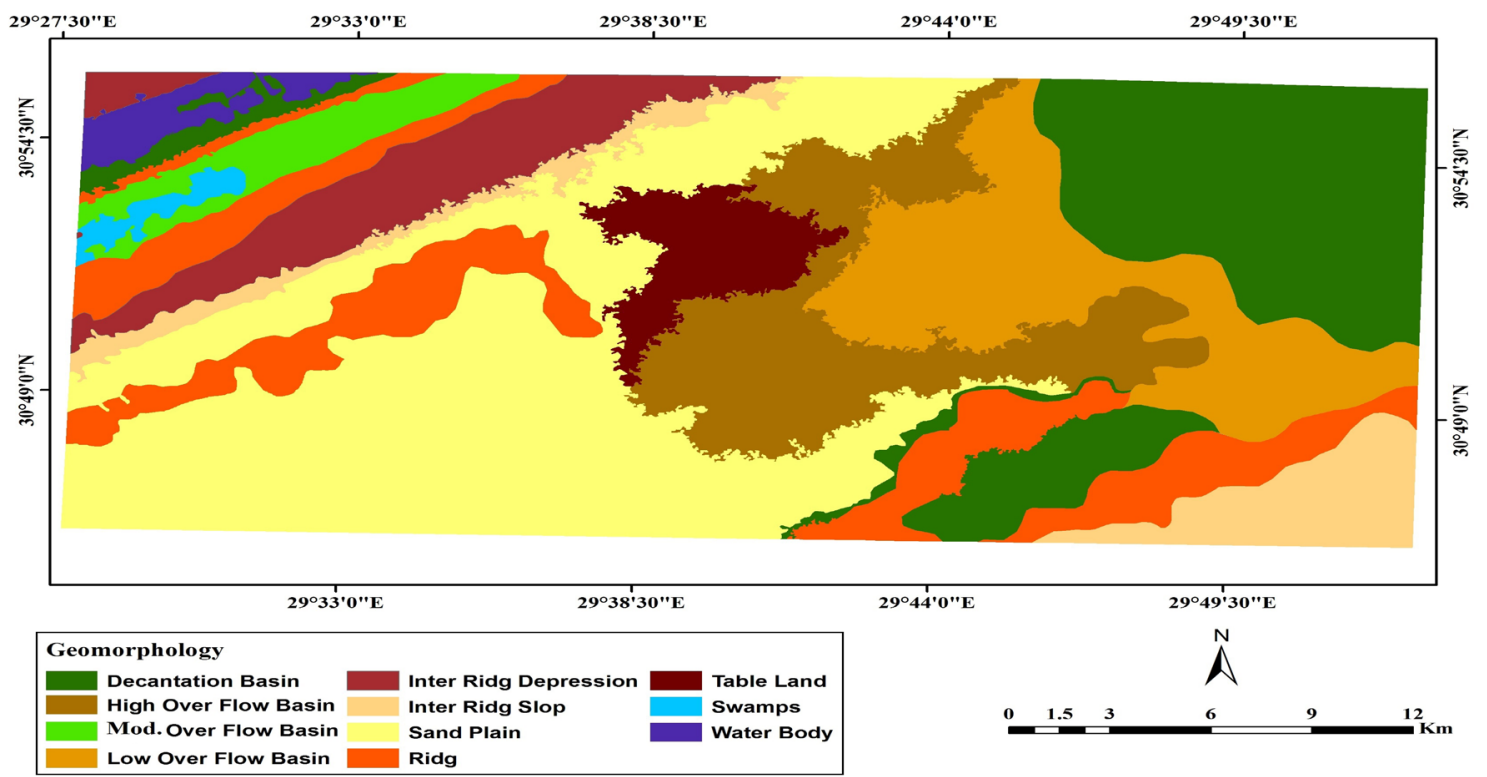

Fig. 2. Physiography of the study area

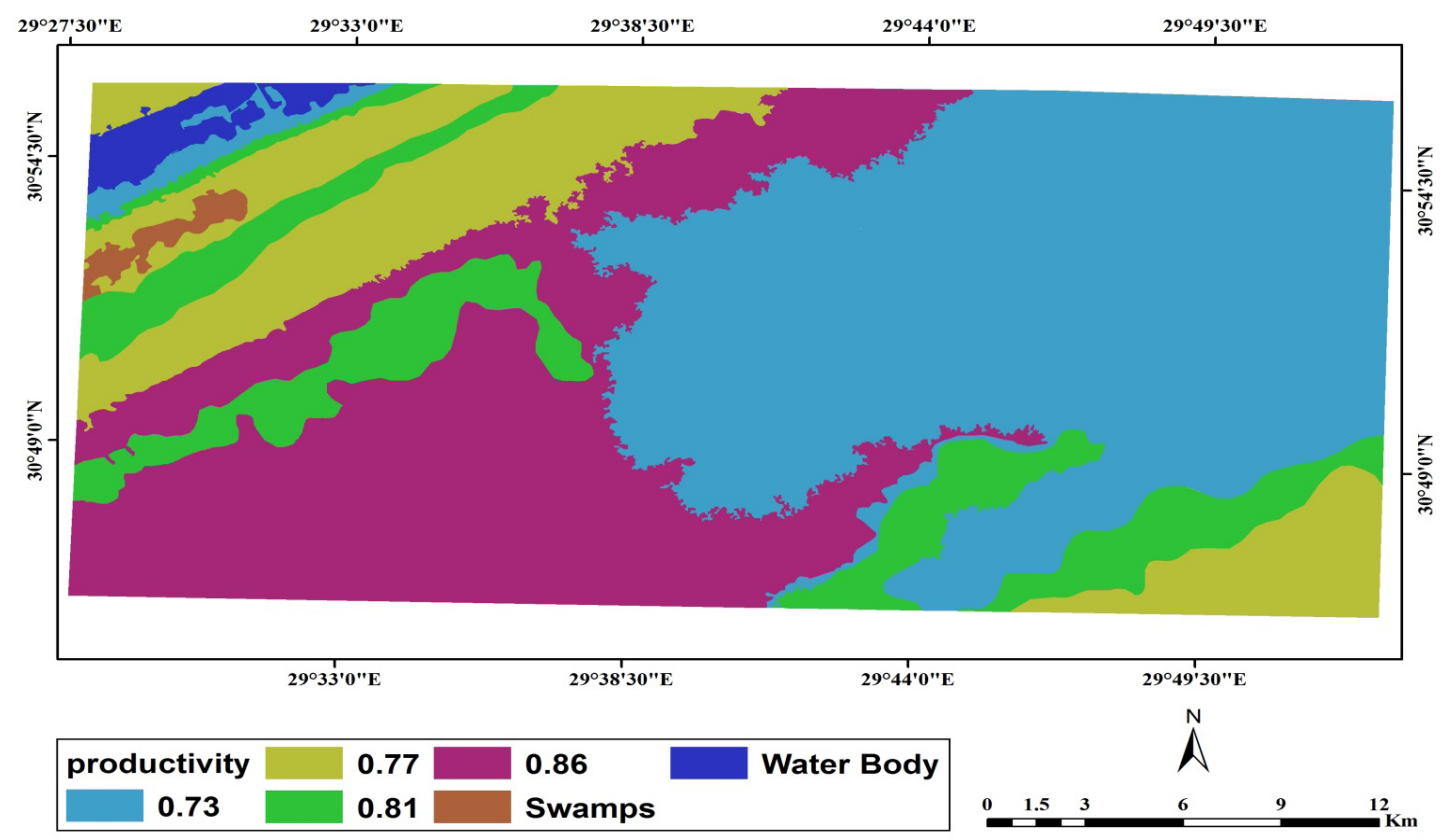

Fig.3. Productivity index of the study area 


\section{Security and protection indices}

Security index shows the relation between biomass and water quality therefore soil moisture, water quality and biomass are used to illustrate the security of agricultural development status of the study area as an indicator for sustainable development. On the other hand, protection index is used to illustrate the susceptibility of the area to erosion hazards by both wind and water. It was found that, low over flow basin and ridge are described by low values of security and protection index where, their values were 0.53 and 0.54 , respectively. The geospatial location and slope degree are the main reasons to decrease their values of security and protection index where, those areas are susceptible to active wind and water erosion as it also causes damage and remove surface soil layers. High over flow basin, table land, over flow basin, inter ridge depression, decantation basin, and inter ridge slope units are described as moderately values varying between $0.6-0.68$ and $0.7-0.85$, in both security and protection respectively. On the other hand, sand plain are attributed by moderate to high values in both indices where they are recorded 0.86 and 0.9 , respectively as shown in Table 3 and Fig. 4 and 5.

\section{Economic viability index}

The economic evaluation depends on several factors related the local economic situation of each region, where it varies from place to another. There is no doubt that the economic situation and the net benefit are the goal of the agricultural process, which includes inputs, outputs, external costs, marketing, etc., the assessment of the economic situation and their affect factors are very important. The results showed variation of the values of economic index, where high over flow basin, decantation basin and table land are attributed by high values of economic index, where attained to 0.81 . Those values of the economic indices are decreased towards the northern west of the study area, where those areas suffering from, insufficient services such marketing and transportation. Therefore the difference in price ate the gate and nearest market is big. At this point, the economic index was attained to 0.58 as shown in Table 4 and Fig. 5.

\section{Social acceptability}

Social acceptability have been evaluated based on six social factors that effects directly on the sustainable agricultural. Those factors considered the main indices of agricultural development in west of Nile delta, where they included healthcare, extension services support, educational support and awareness among the population as well as , training the farmers on modern techniques., agricultural tenure. Furthermore the networks of transportation roads from the farms and villages have been evaluated. The results illustrated that, the social acceptability in general is moderate where their values ranging between 0.68 to 0.77 , except for some parts northwest of the study area that needed improving in some social such as healthcare, education support in addition improving transportation network as shown in Fig. 6 and Table 5.

\section{Agricultural sustainability index}

The agricultural development assessment was based on the five factors mentioned above using spatial modeling and the integration of different layers together using geographic information systems, taking into account the geographical characteristics of each unit as shown in Fig. 7 and Table 6 . The factors used were: soil productivity index (A), security index (B), protection index (C), economic condition index (D) and social index (E) according to the following formula:

Agricultural Sustainability Index $=\mathrm{A} \times \mathrm{B} \times \mathrm{C} \times \mathrm{D} \times \mathrm{E}$

Spatial modeling Agricultural sustainability factors of the study area gave three degrees (II,III and IV) which reflect the current status of the study area as follow:

Class II - The areas of this class are considered in the initial stage of sustained agricultural development despite, are marginally below requested sustainability levels. The areas of this class occupy the middle and south of the study area in sand plain unit. The sustainability values reached 0.36 . It covers an about $11.22 \%$ of the total area.

Class III. The areas characterized by class III are under the initial stage of sustainability development ,its occupies about $64.92 \%$ of the total area and found in the following Physiographic units;- inter ridge depression, high over flow basin, table land, low over flow Basin, inter ridge slope, decantation basin, and over flow basin ,the sustainability values ranging between 0.13 to 0.2 .

Class IV. In this degree, the index of agricultural sustainability has achieved a very low grade less than 0.08 as shown in Table 6 and Fig. 7. Those areas do not fit of sustainable development under the current conditions, as there many obstacles that prevent the development of sustainability indicators, the areas of this class covered about $12.08 \%$ of the total area. 

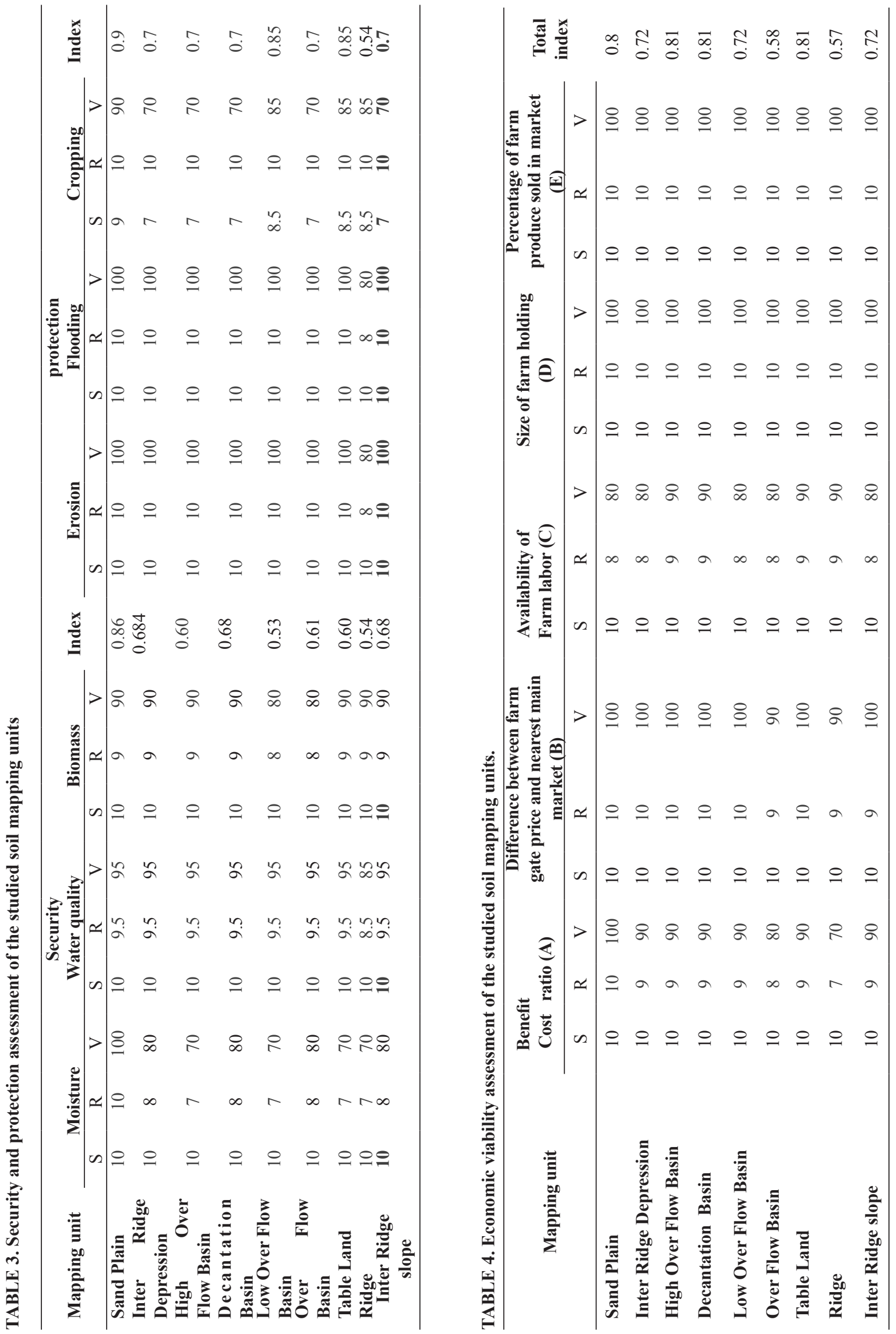

Egypt. J. Soil Sci., 58, No. 3 (2018) 


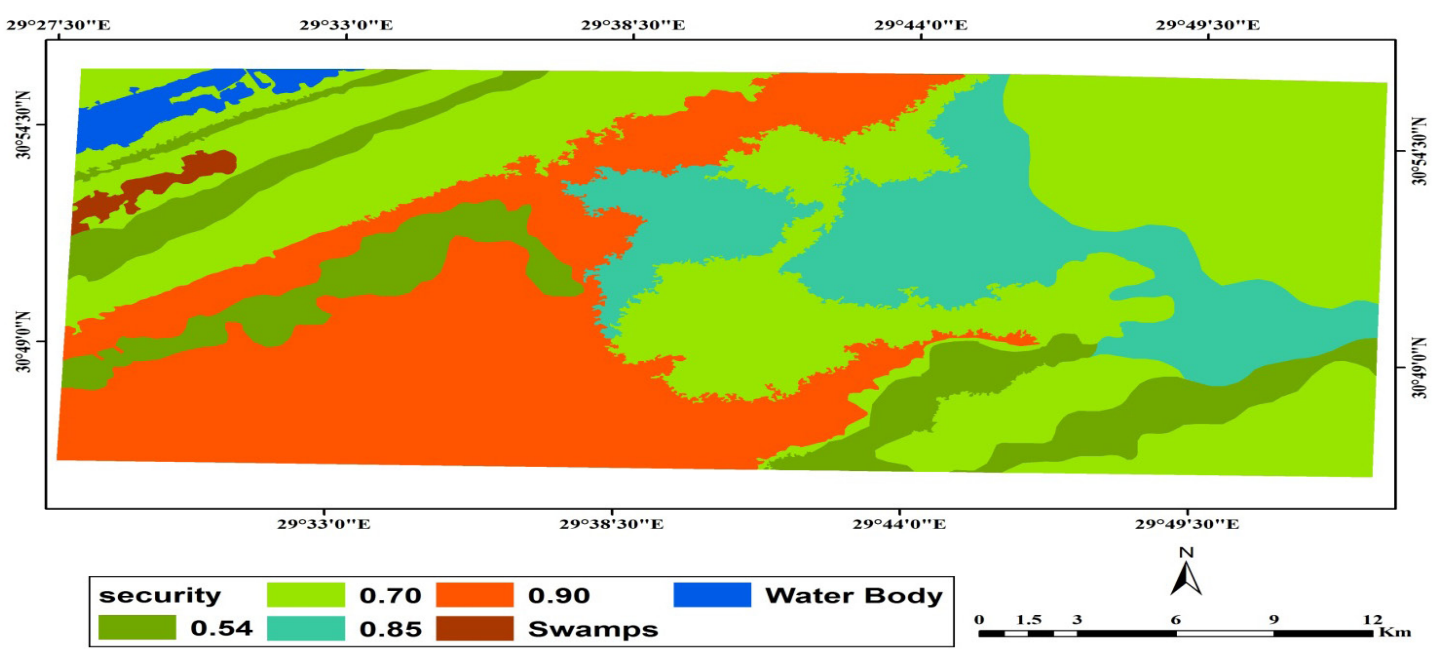

Fig. 4. Security index of the study area.

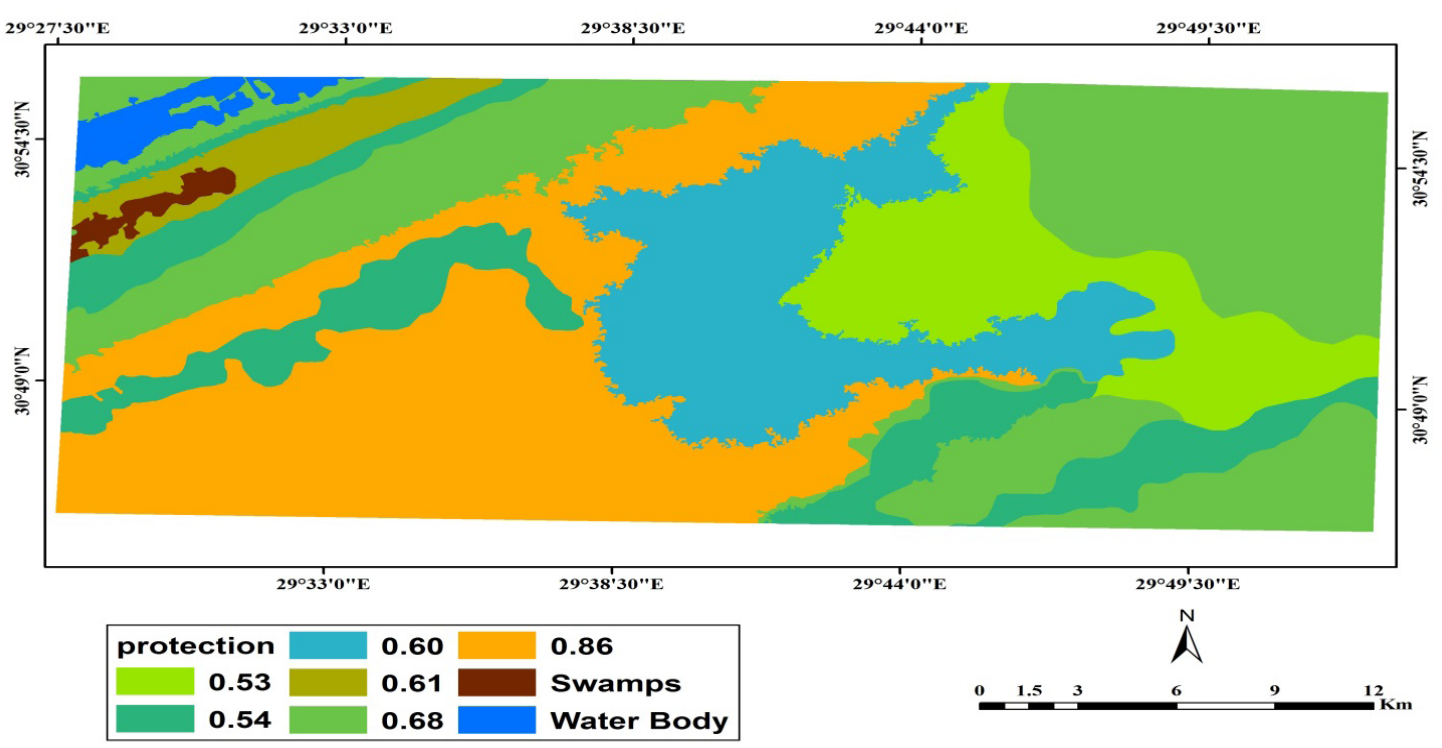

Fig. 5. Protection index of the study area.

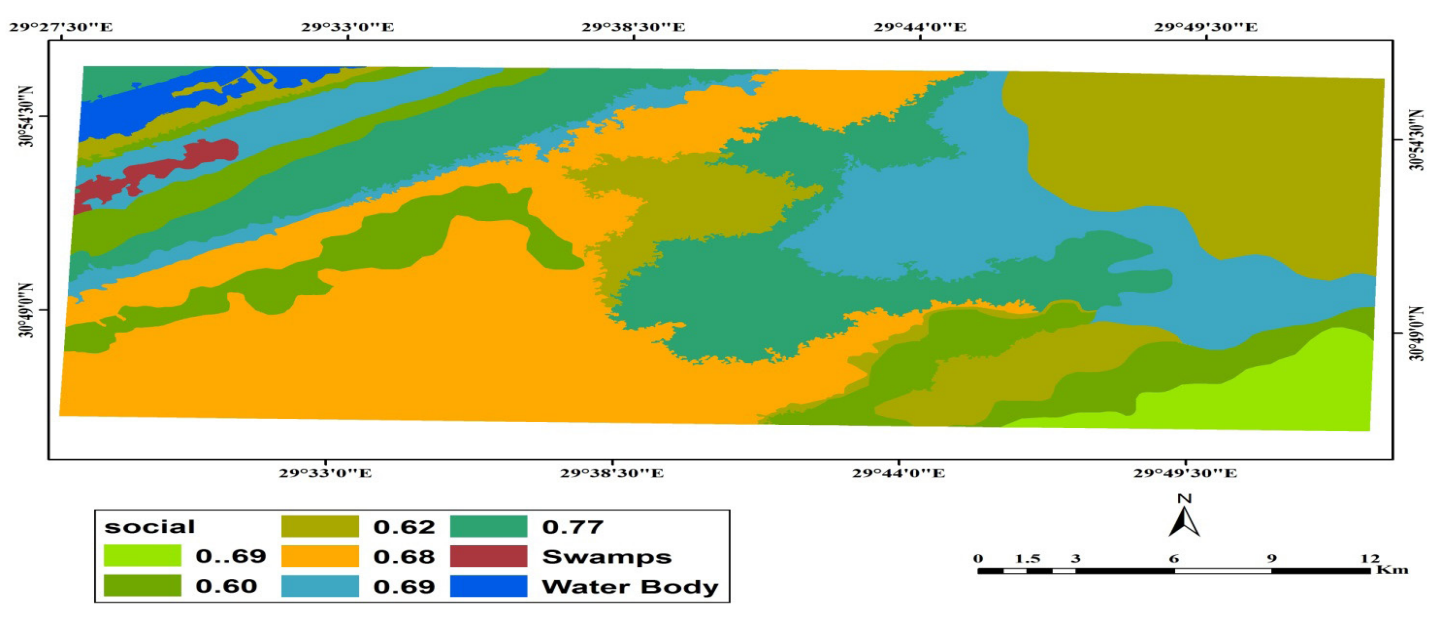

Fig. 6. Social acceptability index of the study area. 


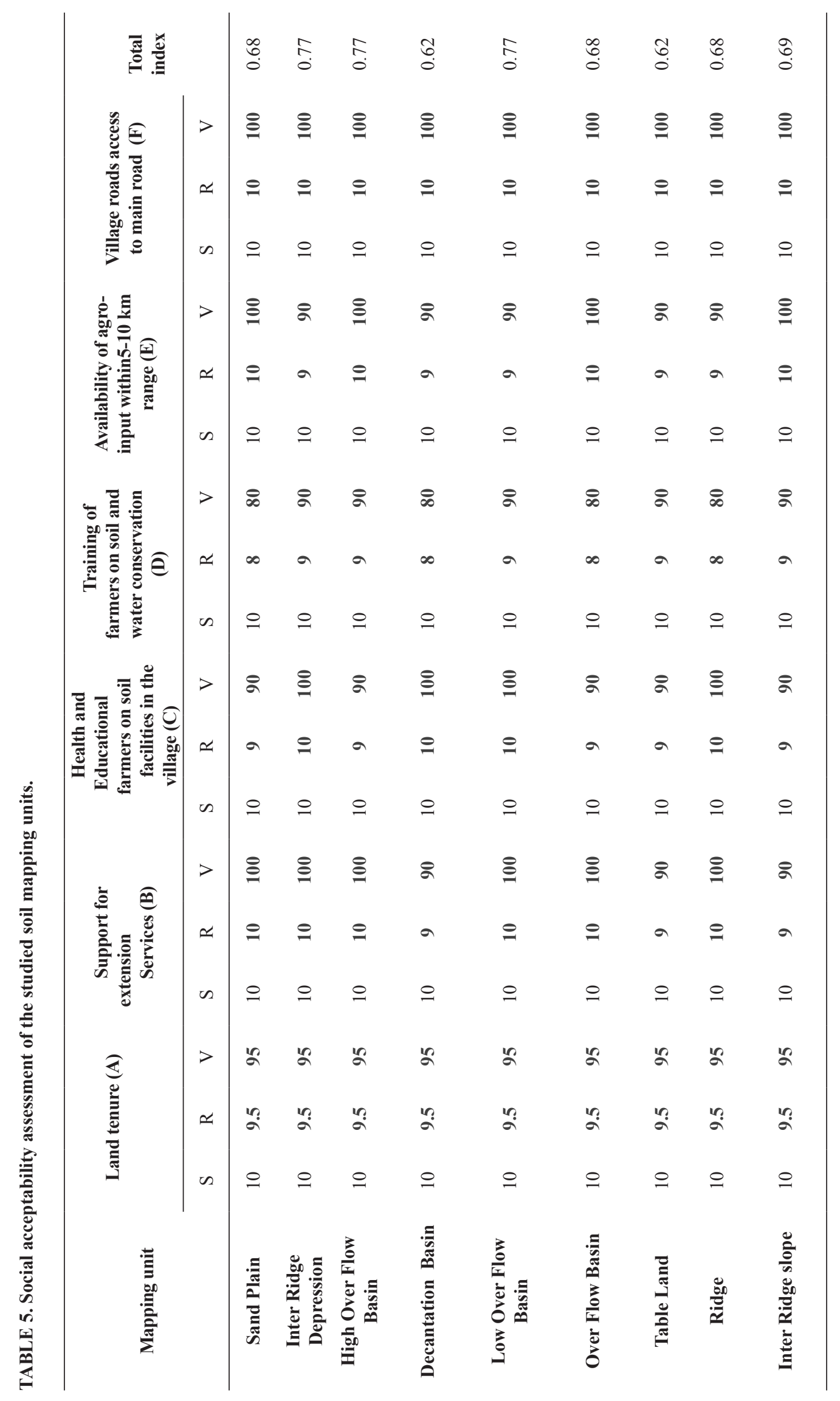

Egypt. J. Soil Sci., 58, No. 3 (2018) 


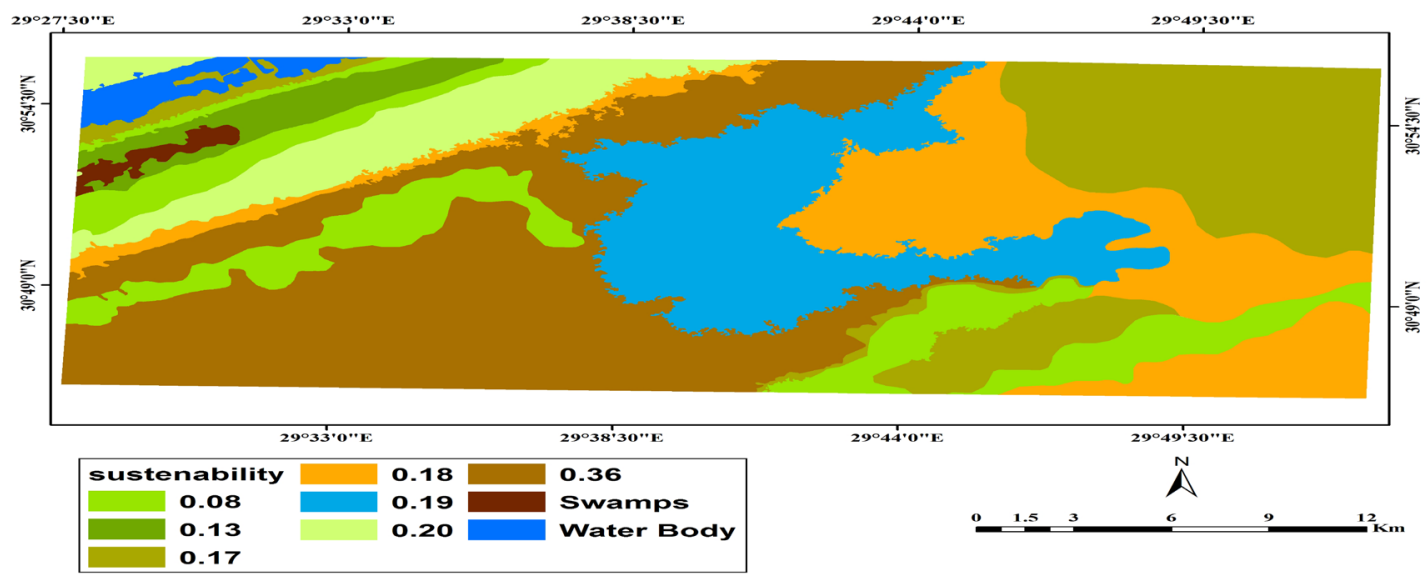

Fig. 7. Current sustainability of the study area

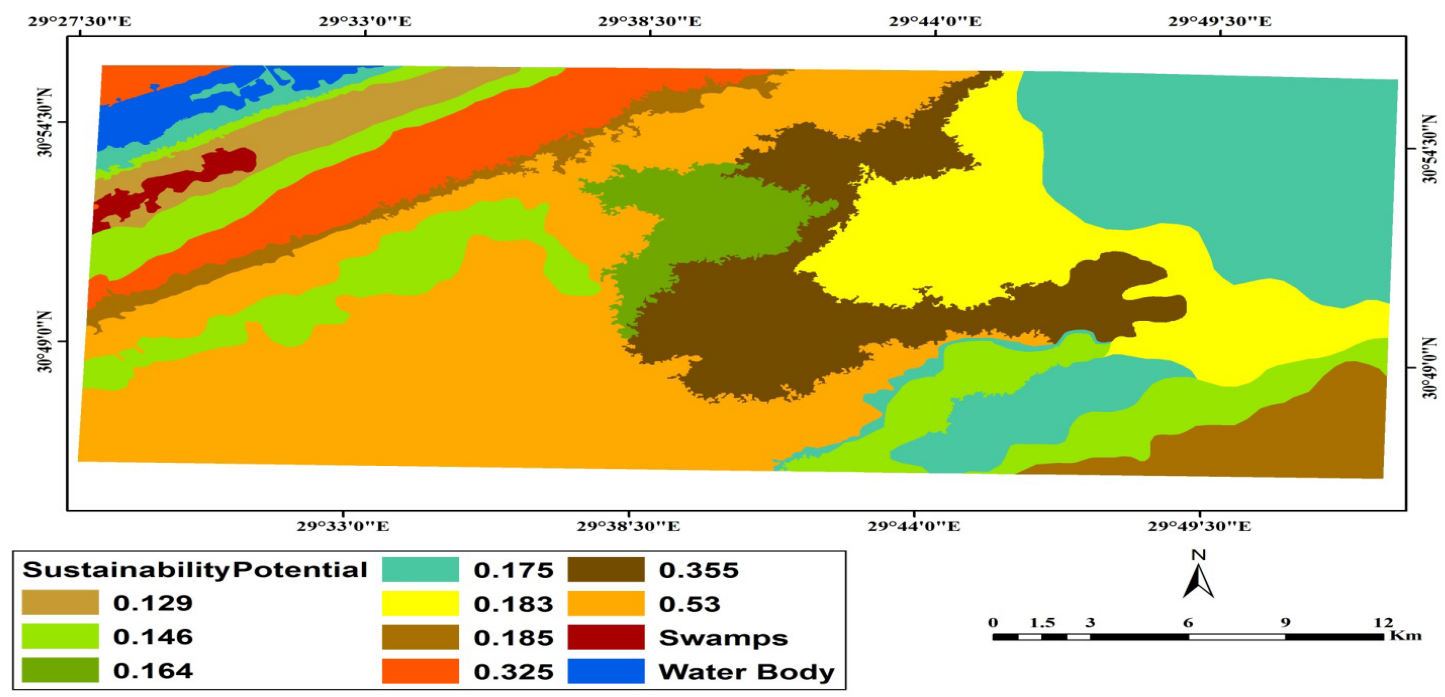

Fig. 8. Potential sustainability of the study area

TABLE 6. Sustainability evaluation on the studied soil mapping units

\begin{tabular}{|c|c|c|c|c|c|c|c|}
\hline $\begin{array}{l}\text { Mapping } \\
\text { unit }\end{array}$ & $\begin{array}{l}\text { Productivity } \\
\text { (A) }\end{array}$ & $\begin{array}{l}\text { Security } \\
\text { (B) }\end{array}$ & $\begin{array}{l}\text { Protection } \\
\text { (C) }\end{array}$ & $\begin{array}{l}\text { Economic } \\
\text { Viability } \\
\text { (D) }\end{array}$ & $\begin{array}{c}\text { Social } \\
\text { Acceptance } \\
\text { (E) }\end{array}$ & $\begin{array}{l}\text { Total } \\
\text { Index }\end{array}$ & $\begin{array}{c}\text { Sustainability } \\
\text { Index }\end{array}$ \\
\hline Sand Plain & 0.86 & 0.86 & 0.90 & 0.80 & 0.68 & 0.36 & II \\
\hline $\begin{array}{l}\text { Inter Ridge } \\
\text { Depression }\end{array}$ & 0.77 & 0.68 & 0.70 & 0.72 & 0.77 & 0.20 & III \\
\hline $\begin{array}{c}\text { High Over Flow } \\
\text { Basin } \\
\text { Decantation }\end{array}$ & 0.73 & 0.60 & 0.70 & 0.81 & 0.77 & 0.19 & III \\
\hline Basin & 0.73 & 0.68 & 0.70 & 0.81 & 0.62 & 0.17 & III \\
\hline $\begin{array}{c}\text { Low Over Flow } \\
\text { Basin }\end{array}$ & 0.73 & 0.53 & 0.85 & 0.72 & 0.77 & 0.18 & III \\
\hline $\begin{array}{l}\text { Over Flow } \\
\text { Basin }\end{array}$ & 0.77 & 0.61 & 0.70 & 0.58 & 0.68 & 0.13 & III \\
\hline Table Land & 0.73 & 0.60 & 0.85 & 0.81 & 0.62 & 0.19 & III \\
\hline Ridge & 0.81 & 0.54 & 0.54 & 0.57 & 0.60 & 0.08 & IV \\
\hline $\begin{array}{l}\text { Inter Ridge } \\
\text { slope }\end{array}$ & 0.77 & 0.68 & 0.70 & 0.72 & 0.69 & 0.18 & III \\
\hline
\end{tabular}


Potential and strategies for development of the study area

The potential sustainability is based on developing the current situations and improving the factors (soil productivity, Security, protection, economic viability, social conditions) based on the current evaluation of the above indices. At this point, some recommendations that could be implemented were proposed to improve overall sustainability of the study area as shown in Table 8 and Fig. 7.

These recommendations regards to improve the public services in the study area which the government and decision makers implement to farmers and their activities that can be used in the future as follows:

a. Constructing new markets in the central's villages to facilitate product marketing and reduce transportation costs then, reflected to decrease fertilizer prices and, maximizes the profit.

b. Facilitate bank loans by reducing interest to encourage the farmers to increase their investments in agricultural projects.

c. Iimprovement of network of road to increase the number of projects and facilitate the transportation between different villages.

d. Increase interest of education for fighting literacy by increasing number of schools

e. Increasing the awareness of farmers about sustainable agricultural management and enhance their capability on using new methods on sustainable agriculture

By applying those recommendations ,the results have changed where, noted that, class II changes from 0.36 to above 0.5 , class III from 0.2 to above 3 and class IV from 0.08 to 0.16 ).

TABLE 7. Sustainability classes of the inspected area.

\begin{tabular}{ccccc}
\hline Sustainability classes & \multicolumn{2}{c}{ Current state } & \multicolumn{2}{c}{ Potential sustainability } \\
\cline { 2 - 5 } & Area\% & Area/Hectares & Area\% & Area/Hectares \\
\hline II & 11.22 & 8367.45 & 58.73 & 44572.67 \\
III & 64.92 & 47657.84 & 26.41 & 200408.57 \\
IV & 12.08 & 9009.74 & 0.00 & 0.00 \\
Reference terms & 12.78 & 9522.53 & 14.9 & 11282.2
\end{tabular}

TABLE 8. Potential sustainability of the study area.

\begin{tabular}{|c|c|c|c|c|c|c|c|}
\hline Mapping unit & $\begin{array}{l}\text { Productivity } \\
\text { (A) }\end{array}$ & $\begin{array}{l}\text { Security } \\
\text { (B) }\end{array}$ & $\begin{array}{l}\text { Protection } \\
\text { (C) }\end{array}$ & $\begin{array}{c}\text { Economic } \\
\text { Viability } \\
\text { (D) }\end{array}$ & $\begin{array}{c}\text { Social } \\
\text { Acceptance } \\
\text { (E) }\end{array}$ & $\begin{array}{r}\text { Total } \\
\text { Index }\end{array}$ & $\begin{array}{l}\text { Sustainability } \\
\text { Index }\end{array}$ \\
\hline Sand Plain & 0.90 & 0.86 & 1.00 & 0.8 & 0.86 & 0.53 & II \\
\hline $\begin{array}{l}\text { Inter Ridge } \\
\text { Depression }\end{array}$ & 0.77 & 0.68 & 0.68 & 0.9 & 1.00 & 0.32 & II \\
\hline $\begin{array}{l}\text { High Over Flow } \\
\text { Basin }\end{array}$ & 0.73 & 0.60 & 0.9 & 0.9 & 1.00 & 0.36 & II \\
\hline $\begin{array}{l}\text { Decantation } \\
\text { Basin }\end{array}$ & 0.73 & 0.68 & 0.68 & 0.81 & 0.62 & 0.17 & III \\
\hline $\begin{array}{l}\text { Low Over Flow } \\
\text { Basin }\end{array}$ & 0.73 & 0.53 & 0.53 & 0.72 & 0.77 & 0.18 & III \\
\hline Over Flow Basin & 0.77 & 0.61 & 0.61 & 0.576 & 0.68 & 0.13 & III \\
\hline Table Land & 0.73 & 0.60 & 0.60 & 0.81 & 0.62 & 0.19 & III \\
\hline Ridge & 0.81 & 0.54 & 0.54 & 0.81 & 0.86 & 0.16 & III \\
\hline Inter Ridge slope & 0.77 & 0.68 & 0.68 & 0.72 & 0.69 & 0.18 & III \\
\hline
\end{tabular}

Egypt. J. Soil Sci., 58, No. 3 (2018) 


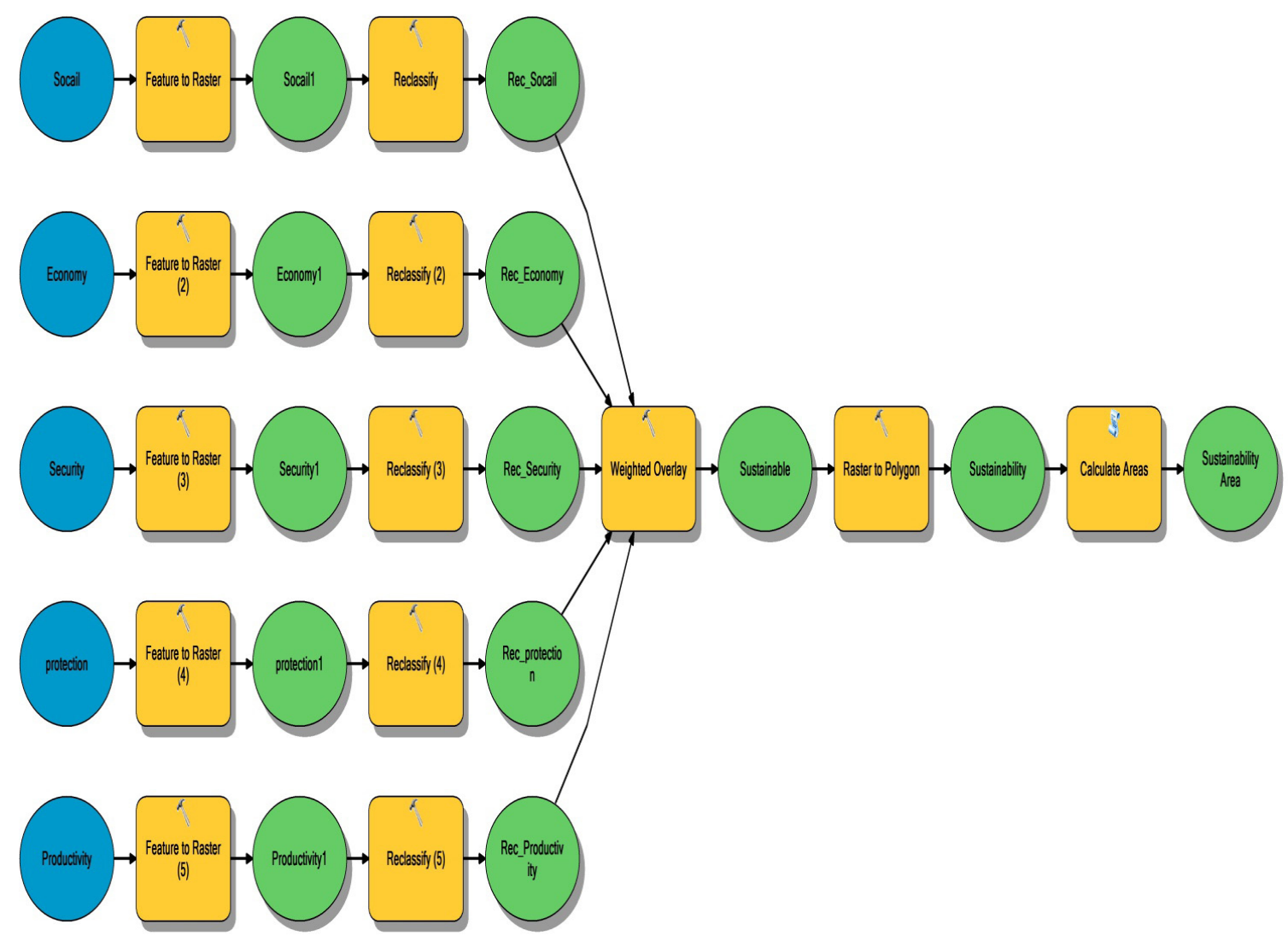

Fig. 9. Decision Supporting System-Sustainable Land Management (DSS-SLM) Model.

\section{Conclusion}

Sustainable agricultural development in Egypt depends on many factors. These factors differ from a place to another according to the conditions of each region where, soil characteristics, geographic location, erosion sensitivity, availability of public services, infrastructure, etc. are essential factors for evaluating the sustainable development. The results illustrated that, three classes are characterized in the study area. Class II - this class covers about $11.22 \%$ of the total area ,the sustainability values reached 0.36 . Class III. occupies about $64.92 \%$ of the total area. Class IV; the areas of this class covered about 12.08 $\%$ of the total area. The study suggested some recommendations that could be implemented to improve overall sustainability of the study area. These recommendations regards to improve the public services in the study area which the government and decision makers can implement to farmers and their activities that can be used in the future.

\section{References}

Abdel Kawy, W., Ali, R., Darwish, Kh. (2012) Sustainable multivariate analysis for land use management in El-Sharkiya, Egypt. Arab. J. Geosci. http://dx.doi.org/10.1007/s12517-012-0758-4.

Antonson, H. (2009) Bridging the gap between research and planning practice concerning landscape in Swedish infrastructural planning. Land Use Policy 26 (2), 169-177.

Bell, S., and Morse, S. (2012) Sustainability indicators: measuring the immeasurable?. Routledge.

Dumanski, J. (1997) Criteria and indicators of land quality and sustainable land management. ITC J. 3 (4), 216-222.

Eswaran, H., Beinroth, F.H., Virmani, S.M. (2000) Resource management domains: a biophysical unit for assessing and monitoring land quality. Agric. Ecosyst. Environ. 81 (2), 155-162. 
El-Nahry, A.H. (2001) An approach for Sustainable Land use Studies of Some Areas in Northwest Nile Delta, Egypt. Ph.D. Thesis, Fac. of Agric, .Cairo Univ., Egypt.

El-Ramady, H.R, El-Marsafawy, Samia M. and Lewis, Lowell N. (2013) Sustainable Agriculture and Climate Changes in Egypt. E. Lichtfouse (Ed.), Sustainable Agriculture Reviews, Sustainable Agriculture Reviews 12, 41 DOI 10.1007/97894-007-5961-9_2, C Springer Science+Business Media Dordrecht 2013

Gliessman, S.R. (1998) Agro ecology: Ecological Process in Sustainable Agriculture. Ann Arbor Press, Chelsea.

Matthews, K.B., Schwarz, G., Buchan, K., Rivington, M., Miller, D. (2008) Wither agricultural DSS? Comput. Electron. Agric. 61, 149-159.

Mohamed E.S., Saleh, A.M. and Belal, A.A. (2014) Sustainability indicators for agricultural land use based on GIS spatial modeling in North of SinaiEgypt.

Mohamed, E.S., Abu-Hashim.,M. and Belal, A.A. (2018) Sustainable Indicators in Arid Region: Case Study - Egypt.DOI 10.1007/698_2018_243.

Muller, A., Ferré, M., Engel, S., Gattinger, A., Holzkämper, A., Huber, R. and Six, J. (2017) Can soil-less crop production be a sustainable option for soil conservation and future agriculture?. Land Use Policy, 69, 102-105
Nawar, S. (2009) Mapping units of some soils of Elsalam Canal basin using the geographic information systems (GIS). MSc, Soil and Water Dep. Suez Canal University

Sharmaa, T., Carmichael, J. and Klinkenberg, B. (2006) Integrated modeling for exploring sustainable agriculture futures. Futures, 38, 93-113.

Simon, S. (2000) An accounting representation of sustainable agriculture practices: the case of biogas agricultural unit in Sichuan. Sustainable Dev. 8, 106-120.

Smyth, A.J., and Dumanski, J. (1993) FESLM: an international framework for evaluating sustainable land management. World Soil Resources Report 73. FAO, Rome

Soil Survey Manual (1993) Soil Survey Division Staff. Soil Conservation Service. U.S.Department of Agriculture Handbook 18.

Tilman, D., Cassman, K.G., Matson, P.A., Naylor, R. and Polasky, S. (2002) Agricultural sustainability and intensive production practices. Nature, 418, 671-677.

USAID (1988) The transition to sustainable agriculture: an agenda for A.I.D. committee for Agric Sustainability For Developing countries, Washington D.C.

(Received: $7 / 5 / 2018$ accepted:12/9/2018) 
تقييم الاستدامة الزراعية في بعض المناطق غرب دلتا النيل

السيد محمد ومحمد سليم جودة

الهيئة القومية للستشعار عن بعد و علوم الفضاء ـ القاهرة وقسم الأراضى ـكلية الزراعة ـجامعة دمياط ـمصر

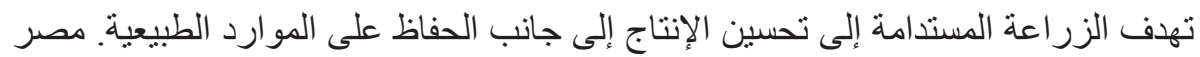

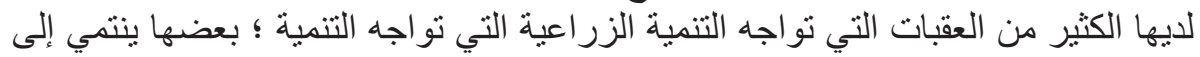

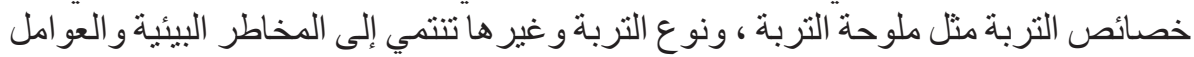

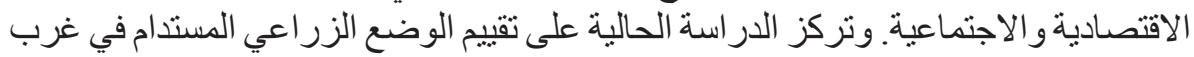

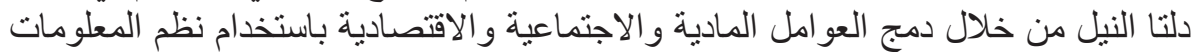

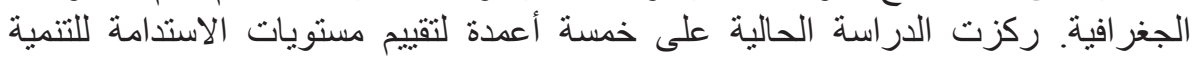

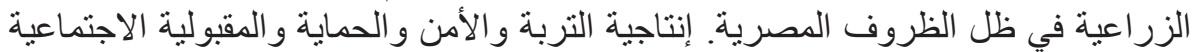

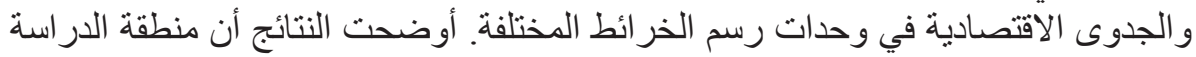

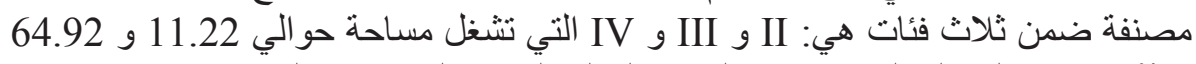

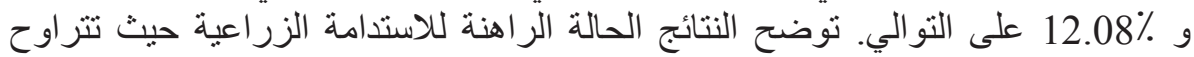

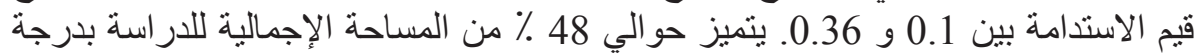

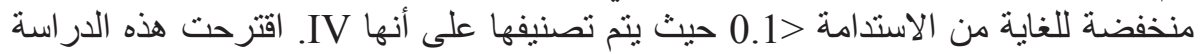

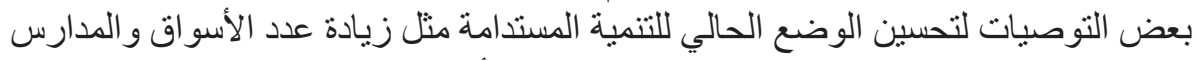

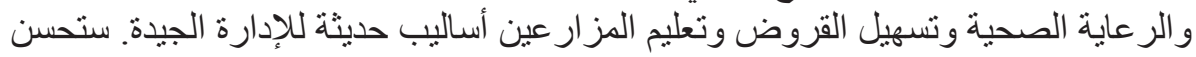
التوصيات المقترحة درجة الاستدامة بنسبة 10 ٪ من منطقة الدربة الدراسة. 